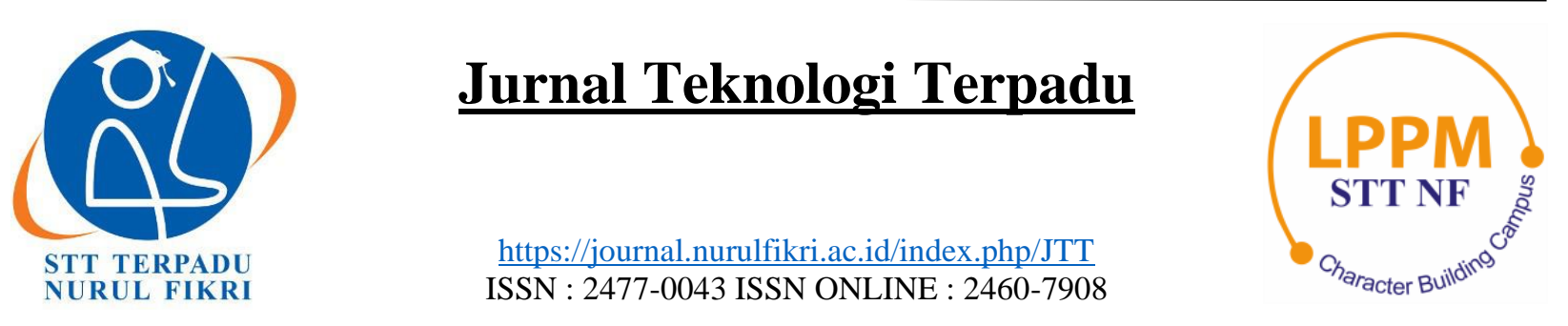

\title{
PENERAPAN LIMIT AKSES BROWSING INTERNET PADA SAAT JAM KERJA DI PT XYZ
}

\author{
Zaenal Mutaqin Subekti ${ }^{1}$, Kikim Mukiman², Ahmad Fikri Adluwal Fadil ${ }^{3}$, Muhammad Asyrofi ${ }^{4}$ \\ ${ }^{1,4}$ Teknik Komputer, Sekolah Tinggi Manajemen Informatika dan Komputer Bani Saleh \\ ${ }^{2}$ Sistem Informasi, Sekolah Tinggi Manajemen Informatika dan Komputer Bani Saleh \\ ${ }^{3}$ Teknik Informatika, Sekolah Tinggi Manajemen Informatika dan Komputer Bani Saleh \\ J1. M Hasibuan No 68, Bekasi, Indonesia 17113 \\ zms.stmikbanisaleh@gmail.com, kikimmukiman@gmail.com, ahmad.fikrinew2801@gmail.com, asyrofimail@gmail.com
}

\begin{abstract}
One of the engineering companies located in the Cikarang area has a rule that every employee is not allowed to access the internet through a browser during working hours, i.e., from 08.00 AM to 12.00 AM and 1.00 to 5.00 PM, only during break time which is between 12.00 AM until 1.00 PM, employees are allowed to access the internet through a browser. The company can apply this rule by implementing its policies on router firewalls to be followed by all employees thoroughly. This research will analyze and implement the process of configuring the router firewalls for the applied case. The first stage of this research starts from analyzing the software and hardware requirements, analyzing the network topology designs, implement the company's policies on firewall configuration, and the last stage is by doing the testing. From this implementation, we get the results that all users cannot access the internet through a browser except for authorized users. These results are applied based on the company's rules and policies proposed above that employees only able to access the internet through a browser during break time and before and after working hours.
\end{abstract}

Keywords: access limit, browser, working hours, firewall, internet

\begin{abstract}
Abstrak
Salah satu perusahaan engineering yang terletak di kawasan Cikarang, mempunyai aturan bahwa setiap karyawan tidak boleh akses internet melalui browser pada jam kerja, yaitu jam 08.00 pagi sampai jam 12.00 dan jam 13.00 sampai jam 17.00 pada saat jam istirahat yaitu jam 12.00 - 13.00 karyawan dapat mengakses internet melalui browser, dengan menerapkan kebijakan perusahaan untuk diimplementasikan pada firewall router, sehingga kebijakan perusahaan tersebut dapat diikuti oleh semua karyawan dengan baik. Tahapan penelitian dimulai dari Analisa untuk menganalisa kebutuhan software dan hardware, kedua desain topologi jaringan, ketiga implementasi kebijakan melalui konfigurasi yang diterapkan pada firewall, keempat melakukan testing. Hasil testing yaitu semua pengguna tidak dapat melakukan akses internet melalui browser pada jam kerja pagi yaitu jam 08.00 sampai jam12.00 dan jam kerja siang jam 13.00 sampai jam 17.00, kecuali bagi user yang dibolehkan, dan semua pengguna dapat mengakses internet, sebelum jam kerja pagi, istirahat makan siang yaitu jam 12.00 sampai jam 13.00 dan setelah jam 17.00 yaitu setelah jam kerja pulang.
\end{abstract}

Kata kunci: limit akses, browser, jam kerja, firewall, internet

\section{PENDAHULUAN}

Berkembangnya teknologi semakin hari semakin cepat, kebutuhan infrastruktur jaringan dibutuhkan dalam menunjang pekerjaan pada salah satu perusahaan engineering di kawasan Hyundai Cikarang, seperti untuk akses data ke server lokal, menyimpan data pekerjaan pada server lokal seperti drawing engineering dan administrasi perkantoran menggunakan aplikasi Office Word atau Excell, serta input data pada sistem gudang. Sharing [1] data komputer [2], akses sharing printer, akses ke sistem gudang untuk input barang masuk dan barang keluar, akses ke sistem produksi lokal, dan penggunaan email [3] client berbasis desktop seperti Ms. Outlook.

Perusahaan mempunyai aturan bahwa setiap karyawan tidak boleh akses browsing internet pada jam kerja yaitu jam 08.00 pagi sampai jam 12.00 dan jam 13.00 sampai jam 17.00 kecuali bagi karyawan yang diperbolehkan. Aturan perusahaan juga mewajibkan karyawan menggunakan email 
berbasis desktop untuk berkomunikasi dengan supplier dan client perusahaan untuk keperluan pekerjaan.

Untuk mengatasi beberapa permasalahan tersebut dengan menerapkan layanan Quality Of Service (QoS) [4], menerapkan limit akses browsing berupa filter [5] pada firewall untuk drop komunikasi dari inbond ke outbond pada port 80 dan 443, kecuali user yang mendapatkan akses browsing internet.

Penelitian terdahulu perancangan pembangunan firewall dan proxy server untuk membatasi hak akses internet dengan menggunakan proxy squid yang terinstall pada Linux Ubuntu 16.10 dengan melakukan Access Control List dapat filter IP address yang boleh akses internet dan memblokir situs-situs tertentu [6]. Implementasi Access Control List menggunakan mikrotik pada SMK Budi Mulia Tanggerang, dengan menerapkan Access Control List dapat membatasi akses media sosial dan streaming video pada saat jam pelajaran [7], pemanfaatan pada web proxy untuk pengoptimalkan keamanan jaringan wireless, dengan menggunakan web proxy pada router mikrotik pada hotspot untuk membatasi akses media sosial dan streaming pada saat jam kerja [8], limitasi pengguna akses internet berdasarkan kuota waktu dan data menggunakan PC router sistem operasi mikrotik dengan mengatur pembagian bandwidth pada setiap pengguna dan pembatasan download maupun upload [9], implementasi Mikrotik Router Board 750 sebagai firewall blok situs pada jaringan LAN untuk melakukan filter terhadap situs-situs web yang berkonten negative hasilnya web yang telah diblokir tidak dapat dibuka oleh pengguna [10]. Tujuan dari penelitian ini adalah pengguna yang masuk pada list IP address blok browsing tidak dapat akses browsing internet pada saat jam kerja dan pengguna yang masuk list IP address allow browsing dapat akses browsing internet pada saat jam kerja.

\section{METODE PENELITIAN}

Tahapan pada penelitian ini ada empat tahapan, pertama di awali dengan melakukan analisa kebutuhan. Kedua dengan melakukan design, yaitu merancang topologi jaringan. Selanjutnya pada tahap ketiga, implementasi menerapkan konfigurasi pada device seperti router. Dan tahapan yang terakhir yaitu testing, melakukan uji coba dari hasil implementasi dan menghasilkan data-data yang dapat digunakan sebagai acuan untuk mendapatkan kesimpulan.

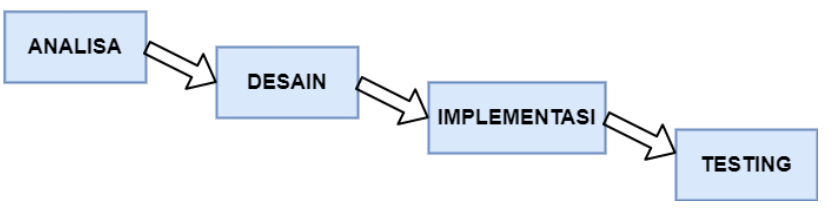

Gambar 1. Tahapan Penelitian

\subsection{Analisa}

Tahapan pertama melakukan analisa. Langkah awal dengan melakukan analisa untuk kebutuhan baik perangkat keras atau perangkat lunak yang akan digunakan pada penelitian ini, kebutuhan perangkat keras meliputi:

Tabel 1. Kebutuhan Perangkat Keras

\begin{tabular}{|c|c|}
\hline $\begin{array}{c}\text { Nama } \\
\text { Perangkat }\end{array}$ & Fungsi \\
\hline Router & $\begin{array}{l}\text { Untuk menerapkan konfigurasi IP address pada } \\
\text { internet dan local area network (LAN), network } \\
\text { address translation, memisahkan penggunaan } \\
\text { bandwidth internet dan lokal, melakukan filter IP } \\
\text { address yang tidak boleh akses ke internet dan yang } \\
\text { dibolehkan serta menambahkan waktu pada user } \\
\text { yang tidak boleh akses internet/browsing. }\end{array}$ \\
\hline Switch & $\begin{array}{l}\text { Perangkat intermediary yang digunakan untuk } \\
\text { menghubungkan dari PC pengguna ke PC pengguna } \\
\text { yang lain atau ke perangkat router. }\end{array}$ \\
\hline Kabel UTP & $\begin{array}{l}\text { Merupakan media atau penghubung dari pengakat } \\
\text { komputer ke switch atau ke router, media yang } \\
\text { digunakan menggunakan tembaga yang balut pada } \\
\text { kabel unshield twisted pair (UTP) }\end{array}$ \\
\hline $\mathrm{PC}$ & $\begin{array}{l}\text { Perangkat yang digunakan pengguna dalam } \\
\text { melakukan pekerjaan baik drawing, administrasi } \\
\text { dengan aplikasi office, input data ke sistem aplikasi, } \\
\text { kirim dan terima email. }\end{array}$ \\
\hline Server & $\begin{array}{l}\text { Sebuah perangkat yang digunakan untuk menyimpan } \\
\text { data terpusat dari pengguna. }\end{array}$ \\
\hline
\end{tabular}

Selanjutnya kebutuhan perangkat lunak, meliputi:

Tabel 2. Kebutuhan Perangkat Lunak

\begin{tabular}{cl}
\hline $\begin{array}{c}\text { Nama } \\
\text { Perangkat }\end{array}$ & \multicolumn{1}{c}{ Fungsi } \\
\hline Winbox & $\begin{array}{l}\text { Sebuah aplikasi yang digunakan untuk melakukan } \\
\text { konfigurasi pada mikrotik melalui Grafik User } \\
\text { Browsing (GUI). }\end{array}$ \\
\hline
\end{tabular}

\subsection{Desain}

Tahapan kedua yaitu desain, pada tahap ini desain topologi jaringan dirancang sesuai dengan kebutuhan dan tata letak pengguna, sehingga topologi jaringan dapat memudahkan dalam menggambarkan dan persiapan untuk mengkonfigurasi router sesuai dengan kebutuhan.

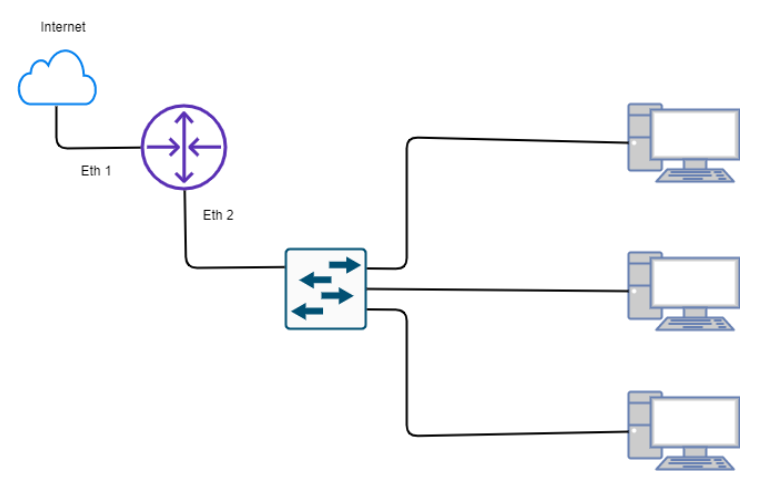

Gambar 2. Topologi Jaringan 


\subsection{Implementasi}

Tahapan ketiga di tahapan penelitian ini adalah implementasi, melakukan konfigurasi atau setting pada device router sesuai dengan kebutuhan, berikut beberapa langkah implementasinya :

- Konfigurasi IP address internet dan local area network

- Konfigurasi Network Address Translation (NAT)

- Konfigurasi DHCP server untuk LAN

- Konfigurasi filter pada firewall untuk IP address yang tidak bisa browsing.

\subsection{Testing}

Tahapan keempat yaitu testing atau pengujian merupakan tahapan untuk melakukan pengujian, setelah melaksanakan analisa, desain, dan implementasi penerapan konfigurasi, serta pengujian akan dilakukan testing bandwidth internet dan bandwidth lokal, pengujian akses browsing pada saat jam kerja dan di luar jam kerja.

\section{HASIL DAN PEMBAHASAN}

Pembahasan dimulai dengan menerapkan konfigurasi pada router sesuai dengan topologi.

\subsection{Konfigurasi Router}

Akses router mikrotik dengan menggunakan Winbox untuk memudahkan konfigurasi berbasis grafik user browsing atau console teks.

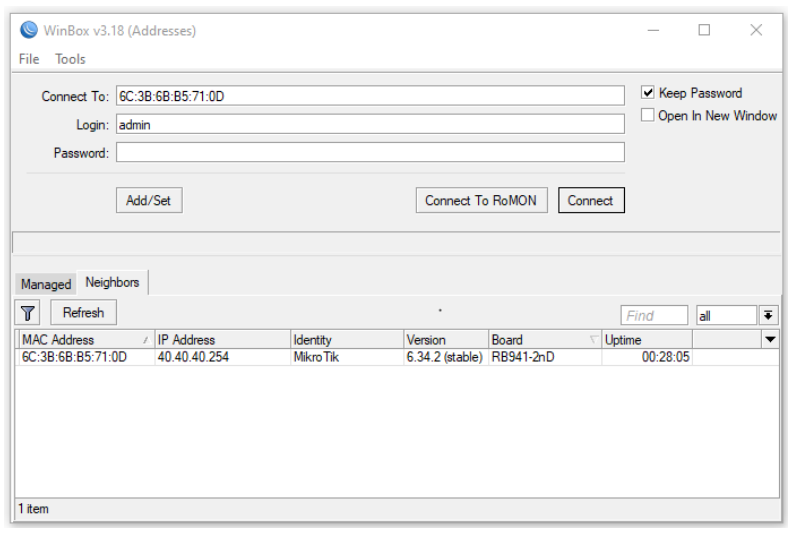

Gambar 3. Winbox

Konfigurasi IP address pada browsing ether1 untuk mendapatkan internet dengan menggunakan layanan DHCP client.

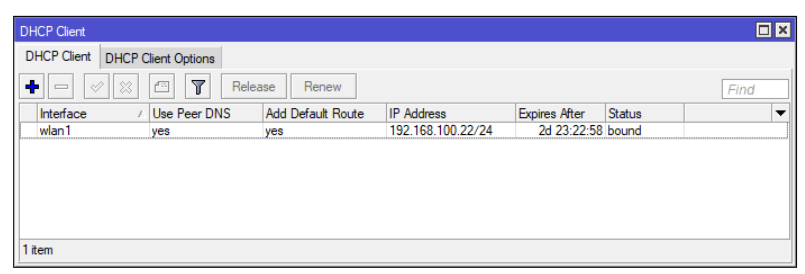

Gambar 4. DHCP Client

Pada DHCP client di tab status mendapatkan status bound menjelaskan bahwa IP address dari internet sudah di dapatkan, selanjutnya, dapat di lakukan testing apakah internet sudah mengalir ke router atau belum. Lakukan dengan klik tab new terminal dan ping ke google.com

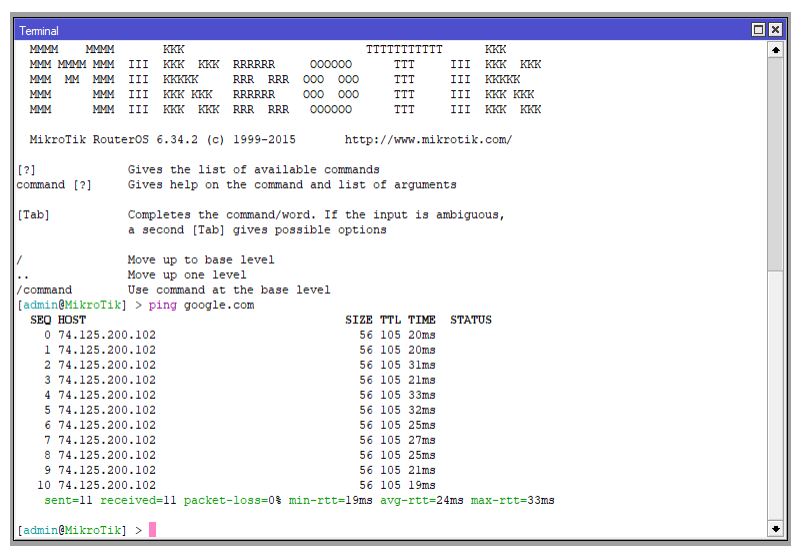

Gambar 5. Pengujian Akses Internet pada Router

Setelah testing berhasil dilajutkan dengan konfigurasi IP address untuk Local Area Network. Klik pada tab IP dan sub tab address, kemudian klik tanda plus dan isi alamat network dan browsing dan klik OK.

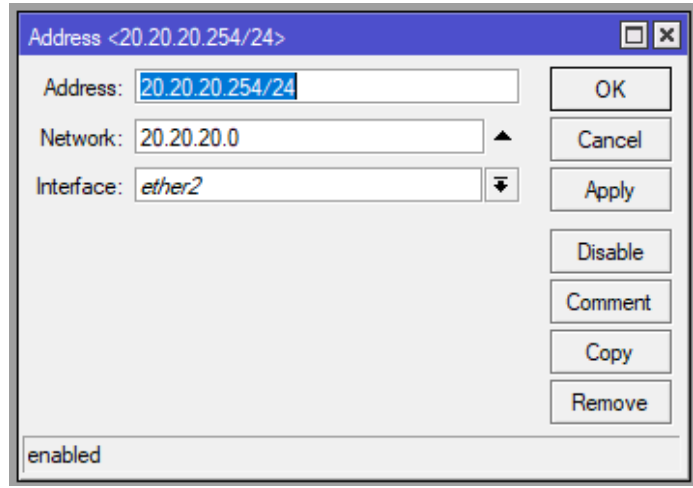

Gambar 6. Pengisian IP Address

Selanjutnya konfigurasi Network Address Translation (NAT) klik pada tab IP dan pilih firewall.

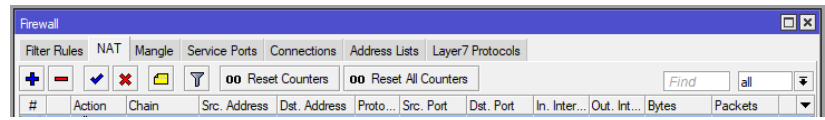

Gambar 7. Firewall

Klik pada tab NAT dan untuk menambah konfigurasi pilih tanda plus, sehingga muncul pop up form new NAT rule, pada chain isi dengan srcnat dan out browsing diisi dengan ether1. 


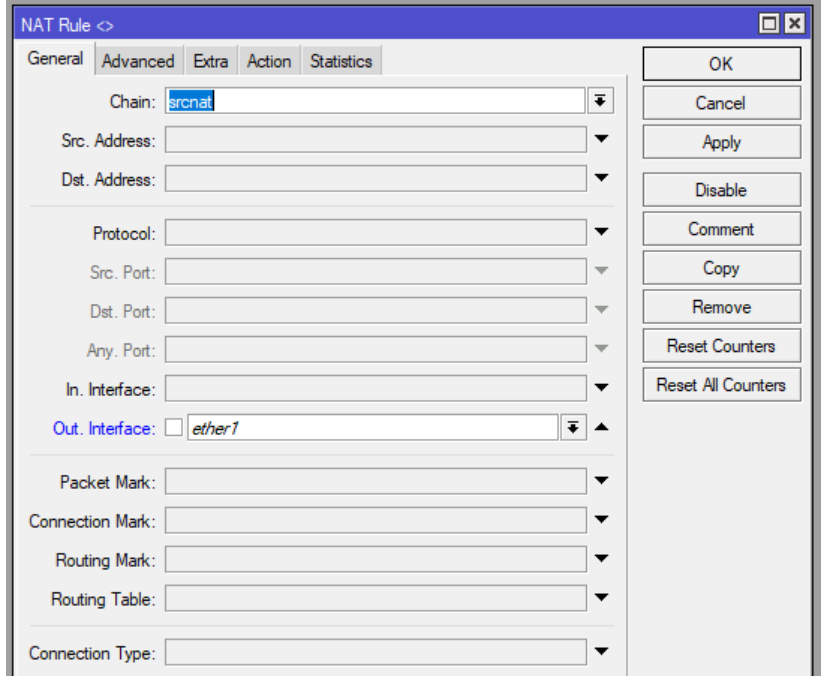

Gambar 8. NAT Rule

Pilih tab action dan pada action pilih masquerade dan klik OK.

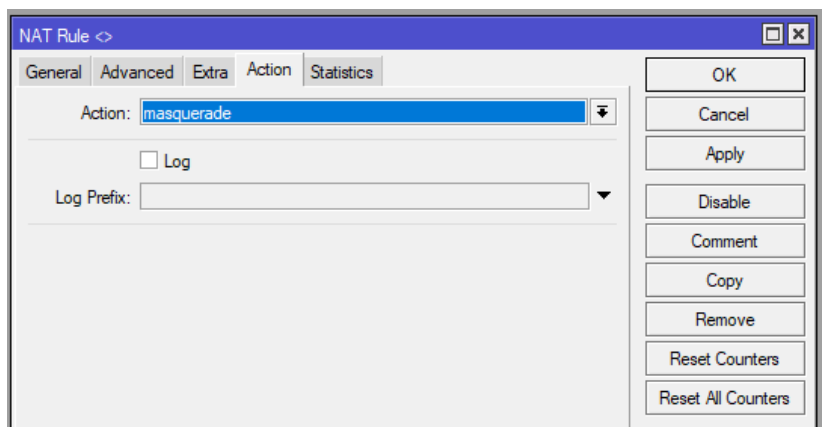

Gambar 9. Action Masquerade

Sehingga menghasilkan baris firewall dengan nomor 0 yang menandakan bahwa baris ini memmpunyai priorotas yang utama.

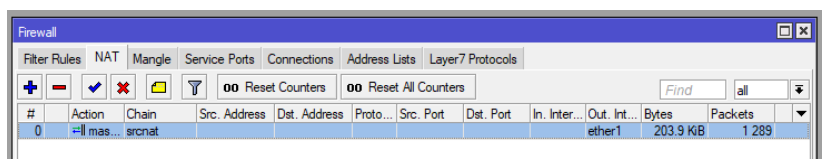

Gambar 10. Firewall NAT

Konfigurasi selanjutnya setup DHCP (Dynamic Host Configuration Protocol) server untuk mensuplay IP address secara otomatis pada ether2 yang terhubung ke LAN. Klik IP dan pilih DHCP server kemudian klik DHCP setup. Selanjutnya pada DHCP setup pilih browsing yang akan di konfigurasi DHCP server, di sini pilih ether2.

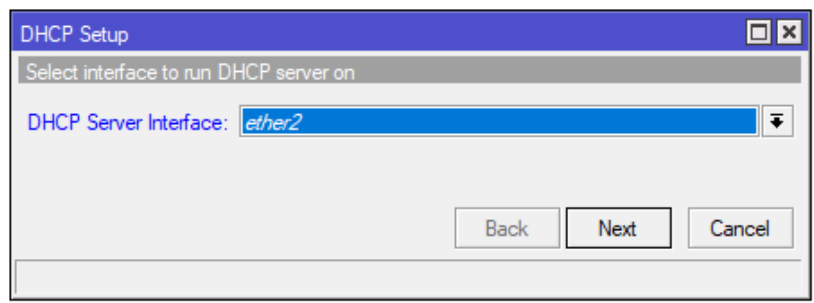

Gambar 11. DHCP Setup
Selanjutnya DHCP address space diisi dengan 20.20.20.0/24.

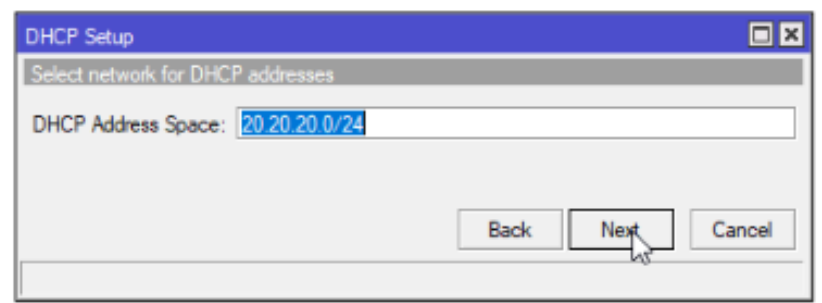

Gambar 12. DHCP Address Space

Setelah next, pengisian IP gateway untuk DHCP network diisi dengan $=20 \cdot 20 \cdot 20.254$.

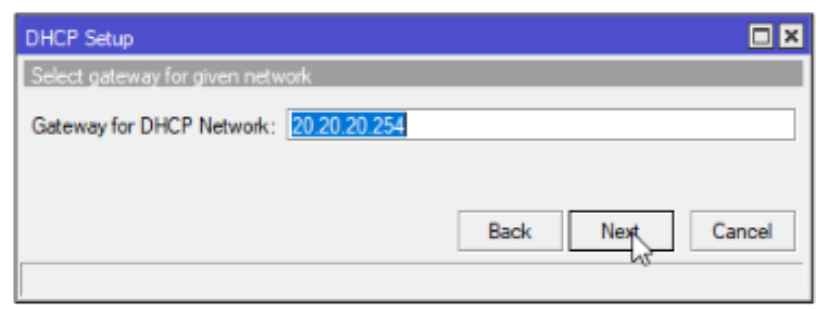

Gambar 13. Gateway for DHCP Network

Klik next, form pengisian selanjutnya mengenai alamat IP address yang akan diisi secara otomatis pada DHCP server, dan setelah diisi klik Next.

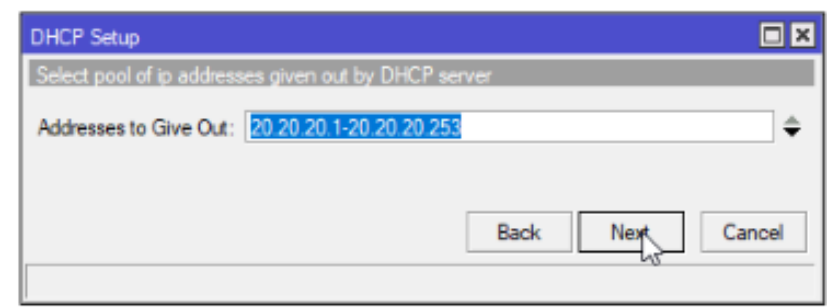

Gambar 14. Address to Give Out

Selanjutnya pengisian pada setup DHCP server untuk DNS server dan klik Next.

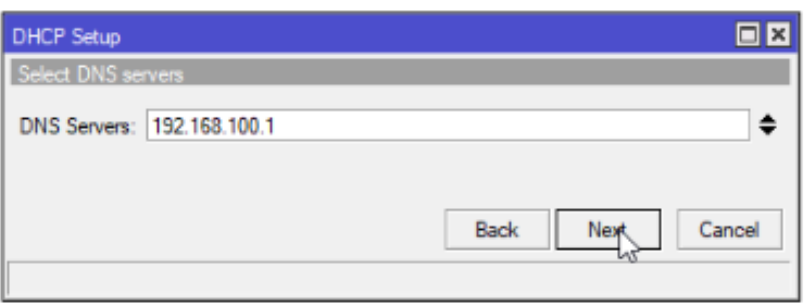

Gambar 15. DNS Server

Yang terakhir pengisian lease time. 


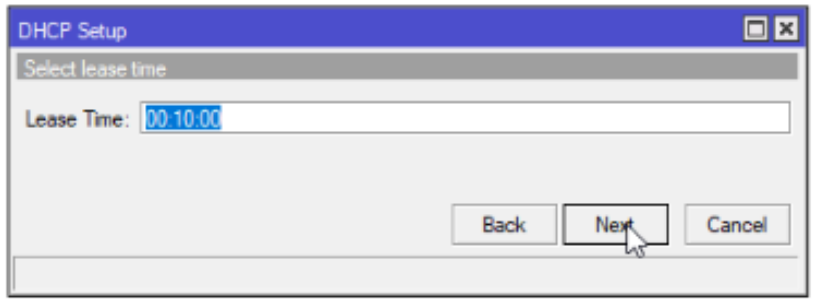

Gambar 16. Lease Time

Setelah selesai akan muncul pop up setup has completed successfully, menandakan bahwa setup DHCP server telah selesai.

Berikut list IP address yang dibolehkan untuk akses browsing internet.

Tabel 3. List IP Address Allow Browsing

\begin{tabular}{ccc}
\hline No & Ip Address & Nama Bagian \\
\hline 1 & 20.20 .20 .253 & Direktur \\
2 & 20.20 .20 .252 & Manager Marketing \\
3 & 20.20 .20 .251 & Manager Produksi \\
4 & 20.20 .20 .250 & Manager Engineering \\
5 & 20.20 .20 .249 & Spv Accounting \\
6 & 20.20 .20 .248 & Spv Engineering \\
7 & 20.20 .20 .247 & Spv Produksi \\
8 & 20.20 .20 .246 & Staff Marketing \\
9 & 20.20 .20 .245 & Staff Purchasing \\
10 & 20.20 .20 .244 & Staff HRD \\
\hline
\end{tabular}

Tabel 4. List IP Address Block Browsing

\begin{tabular}{ccc}
\hline No & Ip Address & Nama Bagian \\
\hline 1 & 20.20 .20 .243 & Staff Produksi \\
2 & 20.20 .20 .242 & Staff Produksi \\
3 & 20.20 .20 .241 & Staff Engineering \\
4 & 20.20 .20 .240 & Staff Engineering \\
5 & 20.20 .20 .239 & Staff Accounting \\
6 & 20.20 .20 .238 & Staff Accounting \\
7 & 20.20 .20 .237 & Sstaff administrasi \\
8 & 20.20 .20 .236 & Staff Gudang \\
\hline
\end{tabular}

Tahap selanjutnya konfigurasi filter firewall untuk menerapkan kebijakan bahwa karyawan tidak boleh akses internet melalui browser pada jam kerja mulai jam 08.00 12.00 dan jam 13.00 - 17.00.

Klik pada tab IP dan pilih firewall nanti akan muncul form firewall. Pada tab address list dan klik tanda plus untuk menambahkan list baru. Pada address list akan digunakan untuk mendaftarkan IP address yang boleh mengakses internet via browsing. Pada name, isi dengan allowbrowsing. Dan pada address, isi dengan IP address yang boleh akses internet contoh di sini 20.20.20.253 dan klik OK.

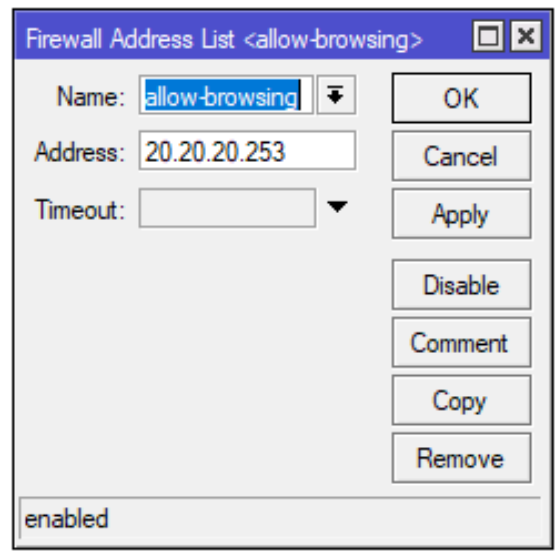

Gambar 17. Firewall Address List

Pada tab filter rules klik icon tanda plus untuk menambahkan rule firewall baru. Setelah muncul form firewall rule pada tab general chain pilih forward, dan protocol pilih 6(tcp) serta pada destination port ketik 80 rule ini akan mengeblok jika pengguna akan mengakses internet via browser dan yang diakses menggunakan HTTP.

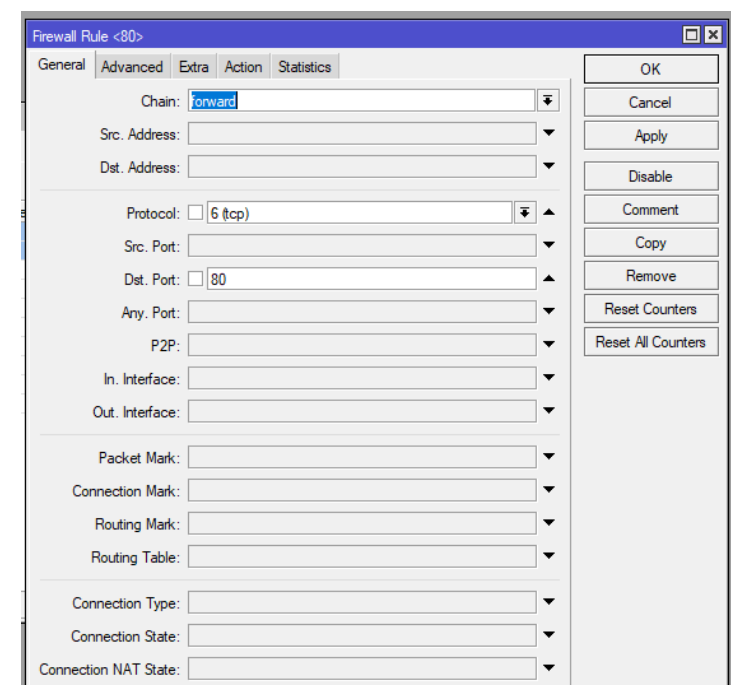

Gambar 18. Tab General Firewall Rule

Pada tab advanced pada source address list, klik tanda seru pada kolom dan pilih allow-browsing. Rule ini akan memberikan IP address yang termasuk pada allow blocking dapat diperbolehkan akses browsing internet. 


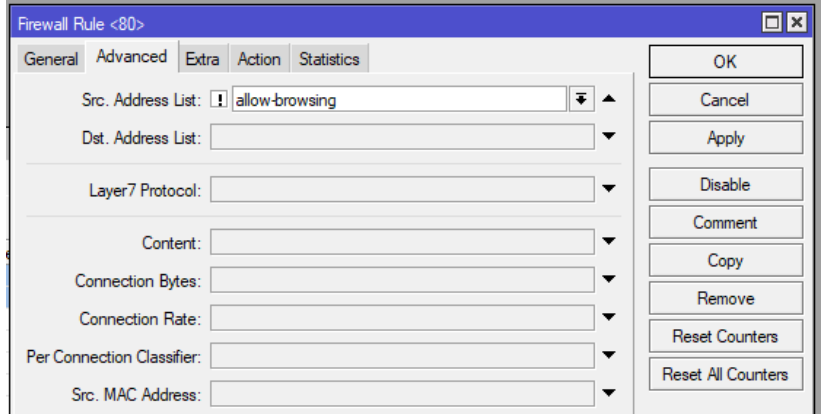

Gambar 19. Tab Advanced Firewall Rule

Pada tab extra, time diisi dengan waktu bloking browsing akses intenet, pada rule ini mengakibatkan pada jam 08.00 - 12.00 akan diblok untuk browsing akses internet.

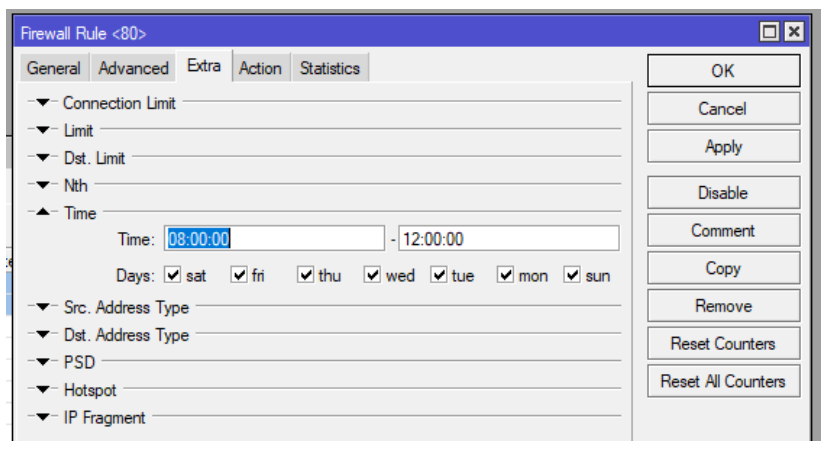

Gambar 20. Tab Extra Firewall Rule

Pada tab action, pilih drop untuk mengeblok jika ada user akan mengakses ke HTTP atau port 80 kecuali jika IP address yang masuk ke dalam allow browser.

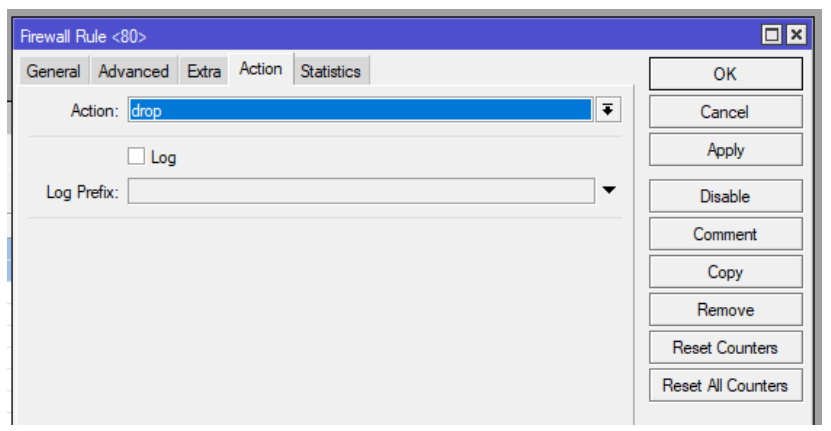

Gambar 20. Tab Action Firewall Rule

Lakukan setting filter firewall seperti Langkah-langkah diatas lagi dengan destination port 443 atau HTTPS, dan extra jam 08.00 - 12.00 sehingga dapat mengblok pengguna yang akan mengakses https pada waktu jam $08.00-12.00$ kecuali IP address yang di allow browsing.

Kemudian lakukan setting filter firewall seperti langkahlangkah seperti di atas dengan destination port 80 atau HTTP dengan extra time 13.00 - 17.00 sehingga dapat melakukan blok pengguna yang akan mengakses HTTP pada waktu, jam 13.00 - 17.00 kecuali IP address yang dibolehkan akses browsing.

Selanjutnya lakukan setting filter firewall seperti langkahlangkah filter rule seperti di atas dengan destination port
443 dan extra time jam 13.00 - 17.00. Sehingga, jika ada pengguna mengakses HTTPS pada jam 13.00 - 17.00 dapat diblok akses internet kecuali IP address yang dibolehkan akses internet.

\subsection{Pengujian}

Pada pengujian dilakukan sebelum menerapkan konfigurasi blok akses browsing internet, dan sesudah menerapkan, berikut hasil pengujian sebelum menerapkan blok akses browsing internet.

Tabel 5. Hasil Pengujian sebelum menerapkan Block Browsing.

\begin{tabular}{|c|c|c|c|}
\hline No & IP Address & Nama Bagian & $\begin{array}{c}\text { Akses } \\
\text { Browsing } \\
\text { Internet }\end{array}$ \\
\hline 1 & 20.20 .20 .253 & Direktur & Berhasil \\
\hline 2 & 20.20 .20 .252 & Manager Marketing & Berhasil \\
\hline 3 & 20.20 .20 .251 & Manager Produksi & Berhasil \\
\hline 4 & 20.20 .20 .250 & Manager Engineering & Berhasil \\
\hline 5 & 20.20 .20 .249 & Spv Accounting & Berhasil \\
\hline 6 & 20.20 .20 .248 & Spv Engineering & Berhasil \\
\hline 7 & 20.20 .20 .247 & Spv Produksi & Berhasil \\
\hline 8 & 20.20 .20 .246 & Staff Marketing & Berhasil \\
\hline 9 & 20.20 .20 .245 & Staff Purchasing & Berhasil \\
\hline 10 & 20.20 .20 .244 & Staff HRD & Berhasil \\
\hline 11 & 20.20 .20 .243 & Staff Produksi & Berhasil \\
\hline 12 & 20.20 .20 .242 & Staff Produksi & Berhasil \\
\hline 13 & 20.20 .20 .241 & Staff Engineering & Berhasil \\
\hline 14 & 20.20 .20 .240 & Staff Engineering & Berhasil \\
\hline 15 & 20.20 .20 .239 & Staff Accounting & Berhasil \\
\hline 16 & 20.20 .20 .238 & Staff Accounting & Berhasil \\
\hline 17 & 20.20 .20 .237 & Sstaff Administrasi & Berhasil \\
\hline 18 & 20.20 .20 .236 & Staff Gudang & Berhasil \\
\hline
\end{tabular}

Pada pengujian tabel 5 diatas, yaitu pengujian sebelum menerapkan block browsing mendapatkan bahwa semua pengguna dapat melakukan akses browsing ke internet pada sebelum jam kerja.

Tabel 6. Hasil Pengujian setelah menerapkan Block Browsing Waktu Pengujian sekitar jam $08.00-12.00$ 


\begin{tabular}{ccll}
\hline No & Ip Address & \multicolumn{1}{c}{ Nama Bagian } & $\begin{array}{c}\text { Akses } \\
\text { Browsing } \\
\text { Internet }\end{array}$ \\
\hline 1 & 20.20 .20 .253 & Direktur & Berhasil \\
2 & 20.20 .20 .252 & Manager Marketing & Berhasil \\
3 & 20.20 .20 .251 & Manager Produksi & Berhasil \\
4 & 20.20 .20 .250 & Manager Engineering & Berhasil \\
5 & 20.20 .20 .249 & Spv Accounting & Berhasil \\
6 & 20.20 .20 .248 & Spv Engineering & Berhasil \\
7 & 20.20 .20 .247 & Spv Produksi & Berhasil \\
8 & 20.20 .20 .246 & Staff Marketing & Berhasil \\
9 & 20.20 .20 .245 & Staff Purchasing & Berhasil \\
10 & 20.20 .20 .244 & Staff HRD & Berhasil \\
11 & 20.20 .20 .243 & Staff Produksi & Gagal \\
12 & 20.20 .20 .242 & Staff Produksi & Gagal \\
13 & 20.20 .20 .241 & Staff Engineering & Gagal \\
14 & 20.20 .20 .240 & Staff Engineering & Gagal \\
15 & 20.20 .20 .239 & Staff Accounting & Gagal \\
16 & 20.20 .20 .238 & Staff Accounting & Gagal \\
17 & 20.20 .20 .237 & Sstaff administrasi & Gagal \\
18 & 20.20 .20 .236 & Staff Gudang & Gagal \\
\hline & & &
\end{tabular}

Pada pengujian tabel 6 di atas, yaitu pengujian setelah menerapkan block browsing waktu pengujian sekitar jam 08.00 - 12.00 mendapatkan pengguna yang terdapat pada list IP address block browsing tidak dapat akses browsing internet pada jam 08.00 - 12.00, dan pengguna yang terdapat list IP address allow browsing dapat mengakses internet melalui browser.

Tabel 7. Hasil Pengujian setelah menerapkan Blok Browsing Waktu Pengujian sekitar jam 12.00 - 13.00 atau Waktu Istirahat Makan Siang

\begin{tabular}{|c|c|c|c|}
\hline No & Ip Address & Nama Bagian & $\begin{array}{c}\text { Akses } \\
\text { Browsing } \\
\text { Internet }\end{array}$ \\
\hline 1 & 20.20 .20 .253 & Direktur & Berhasil \\
\hline 2 & 20.20 .20 .252 & Manager Marketing & Berhasil \\
\hline 3 & 20.20 .20 .251 & Manager Produksi & Berhasil \\
\hline 4 & 20.20 .20 .250 & Manager Engineering & Berhasil \\
\hline 5 & 20.20 .20 .249 & Spv Accounting & Berhasil \\
\hline 6 & 20.20 .20 .248 & Spv Engineering & Berhasil \\
\hline 7 & 20.20 .20 .247 & Spv Produksi & Berhasil \\
\hline 8 & 20.20 .20 .246 & Staff Marketing & Berhasil \\
\hline 9 & 20.20 .20 .245 & Staff Purchasing & Berhasil \\
\hline 10 & 20.20 .20 .244 & Staff HRD & Berhasil \\
\hline 11 & 20.20 .20 .243 & Staff Produksi & Berhasil \\
\hline 12 & 20.20 .20 .242 & Staff Produksi & Berhasil \\
\hline 13 & 20.20 .20 .241 & Staff Engineering & Berhasil \\
\hline 14 & 20.20 .20 .240 & Staff Engineering & Berhasil \\
\hline 15 & 20.20 .20 .239 & Staff Accounting & Berhasil \\
\hline 16 & 20.20 .20 .238 & Staff Accounting & Berhasil \\
\hline 17 & 20.20 .20 .237 & Staff administrasi & Berhasil \\
\hline 18 & 20.20 .20 .236 & Staff Gudang & Berhasil \\
\hline
\end{tabular}

Pada pengujian tabel 7 di atas, yaitu setelah menerapkan blok browsing waktu pengujian sekitar jam 12.00 - 13.00 atau waktu istirahat makan siang mendaptkan semua pengguna dapat mengakses browsing ke internet, karena pada jam tersebut dibolehkan semua karyawan dapat mengakses internet.

Tabel 8. Hasil Pengujian setelah menerapkan Block Browsing Waktu Pengujian sekitar jam $13.00-17.00$

\begin{tabular}{ccll}
\hline No & IP Address & \multicolumn{1}{c}{ Nama Bagian } & $\begin{array}{c}\text { Akses } \\
\text { Browsing } \\
\text { Internet }\end{array}$ \\
\hline 1 & 20.20 .20 .253 & Direktur & Berhasil \\
2 & 20.20 .20 .252 & Manager Marketing & Berhasil \\
3 & 20.20 .20 .251 & Manager Produksi & Berhasil \\
4 & 20.20 .20 .250 & Manager Engineering & Berhasil \\
5 & 20.20 .20 .249 & Spv Accounting & Berhasil \\
6 & 20.20 .20 .248 & Spv Engineering & Berhasil \\
7 & 20.20 .20 .247 & Spv Produksi & Berhasil \\
8 & 20.20 .20 .246 & Staff Marketing & Berhasil \\
9 & 20.20 .20 .245 & Staff Purchasing & Berhasil \\
10 & 20.20 .20 .244 & Staff HRD & Berhasil \\
11 & 20.20 .20 .243 & Staff Produksi & Gagal \\
12 & 20.20 .20 .242 & Staff Produksi & Gagal \\
13 & 20.20 .20 .241 & Staff Engineering & Gagal \\
14 & 20.20 .20 .240 & Staff Engineering & Gagal \\
15 & 20.20 .20 .239 & Staff Accounting & Gagal \\
16 & 20.20 .20 .238 & Staff Accounting & Gagal \\
17 & 20.20 .20 .237 & Sstaff Administrasi & Gagal \\
18 & 20.20 .20 .236 & Staff Gudang & Gagal \\
\hline
\end{tabular}

Pada pengujian tabel 8 di atas, yaitu pengujian setelah menerapkan block browsing waktu pengujian sekitar jam 13.00 - 17.00 mendapatkan pengguna yang terdapat pada List IP address block browsing tidak dapat akses browsing internet pada jam 13.00 - 17.00, dan pengguna yang terdapat list IP address allow browsing dapat mengakses internet melalui browser.

\section{KESIMPULAN}

Dari tabel hasil pengujian di atas, sebelum menerapkan blocking browsing akses internet dari semua pengguna dapat mengakses browsing internet. Pada hasil pengujian setelah menerapkan block browsing waktu pengujian sekitar jam 08.00 sampai jam 12.00 pengguna yang termasuk pada list IP address allow browsing dapat mengakses internet, sedangkan pangguna yang tidak masuk pada list allow browsing tidak dapat browsing internet. Hasil pengujian setelah menerapkan blok browsing waktu pengujian sekitar jam 12.00 sampai jam 13.00 atau waktu istirahat makan siang, semua karyawan dapat mengakses browsing internet, hasil pengujian yang terakhir pengujian setelah menerapkan blok browsing waktu pengujian sekitar jam 13.00 sampai jam 17.00, karyawan yang masuk pada list IP address allow browsing dapat mengakses browsing internet dan karyawan yang IP address nya tidak masuk pada list allow browsing 
tidak dapat akses browsing internet, ini menunjukkan dengan metode filter pada firewall router mikrotik dapat melakukan limit akses browsing internet pada jam kerja di salah satu perusahaan engineering di Cikarang. Tentunya kebijakan ini hanya digunakan untuk bekerja pada kantor atau work form office.

\section{Ucapan Terima Kasih}

Terima kasih kepada LPPM STMIK Bani Saleh yang memberikan kesempatan untuk melaksanakan penelitian dosen internal di STMIK Bani Saleh.

\section{DAFTAR PUSTAKA}

[1] A. Nugroho and Y. Handrianto, "File Sharing Server menggunakan Samba Server dan Linux Ubuntu 12.04 Server," Paradig. - J. Komput. dan Inform., vol. 18, no. 2, pp. 11-17, 2016.

[2] Z. M. Subekti, "Implementasi Keamanan Akses Sharing Folder pada Windows 10," vol. 11, no. 1, 2021.

[3] M. A. Sutisna, M. T. Informasi, U. A. Dahlan, I. Riadi, M. Kom, and J. Soepomo, “Analisa Forensik pada Email Spoofing," J. Teknol. Terpadu, vol. 4, no. 1, pp. 38-43, 2018.

[4] R. Muzawi, and R. Hardianto, "Perancangan Server dan Analisis Quality of Service (QoS) Jaringan Diskless PXE Linux pada Laboratorium Komputer STMIK-Amik-Riau," J. INOVTEK POLBENG-Seri
Informatika, vol. 1, no. 1, 2016.

[5] A. T. Laksono and M. A. H. Nasution, "Implementasi Keamanan Jaringan Komputer Local Area Network menggunakan Access Control List pada Perusahaan X," J. Sist. Komput. dan Inform., vol. 1, no. 2, p. 83, 2020.

[6] N. Suryana, "Perancangan Penggunaan Firewall dan Proxy Server untuk Membatasi Hak Akses Internet," J. Sutet, vol. 8, no. 1, pp. 44-53, 2019.

[7] I. W. D. Alfian Aji Saputra, "Implementasi Access Control List menggunakan Mikrotik pada SMK Budi Mulia Tangerang," Jurnal IDEALIS, vol. 1, no. 5, pp. 401-408, 2019.

[8] Noviansyah, "Pemanfaatan Web Proxy sebagai Pengoptimal Keamanan," J. KhatuListiwa Inform., vol. 8, no. 1, pp. 34-39, 2020.

[9] R. D. H. Ontoseno, M. N. Haqqi, and M. Hatta, "Limitasi Pengguna Akses Internet berdasarkan Kuota Waktu dan Data menggunakan PC Router Os Mikrotik," Tek. Eng. Sains J., vol. 1, no. 2, p. 125, 2017.

[10] M. Siddik, "Implementasi Mikrotik Router Board 750 sebagai Firewall Blok Situs pada Jaringan LAN," JURTEKSI (Jurnal Teknol. dan Sist. Informasi), vol. 3, no. 2, pp. 70-75, 2019. 